\title{
Counterprivates: An Appeal to Rethink Suburban Interiority
}

\author{
Jessica Blaustein
}

Ordinary memory knows it so well that it sings, in all languages, of the sweetness of one's "home, sweet home." Yet, the enclosed garden where the body hides its pains and joys is not a "forbidden city." If it does not want to become a synonym for a terrible house arrest, separated from the living, the private space must know how to open itself up to the flow of people coming in and out, to be the passageway for a continual circulation, where objects, people, words, and ideas cross paths; for life is also about mobility, impatience for change, and relation to a plurality of others. Only a dead language no longer changes; only the absence of all residents respects the immovable order of things. Life maintains and displaces; it wears out, breaks, and reworks; it creates new configurations of beings and objects across the everyday practices of the living, always similar and different. Private space is this ideal city in which all the passersby have beloved faces, whose streets are familiar and safe, whose interior architecture is changeable almost at will.

-Michel de Certeau and Luce Giard, The Practice of Everyday Life, vol. 2

\section{Home Sweet Home}

While imaginations of dwelling cannot but proliferate unpredictably, these pages begin with a more paranoid tale about "privates" - the oft-imagined private domain

Jessica Blaustein is a Mellon Postdoctoral Fellow in English at the University of Pennsylvania, where she teaches and writes at the intersections of American literature, architecture, urban studies, and critical theory. Her current research focuses on anti-sedentarist theories of subject and community formation, and she is preparing a book manuscript about alternative practices of privacy in the early twentieth century United States. 
of the detached single-family variety of American home sweet homes and the socalled private territory of the self, of personhood. In the first two decades of the twentieth century, both spaces converged in an unequivocally suburban form of American individualism that not only impacted material forms of dwelling along residential landscapes, but substantially limited so-called "proper" affective and sexual life to the insides of house-bound nuclear familial units, while it forcefully kept other kinds of connections and identifications out.

Of course, I am here reiterating an ideal-the model home and incubator of nuclear families and model citizens, of personal happiness and domestic contentnot to prove it illusory, but to grapple with its very real hold over so much of everyday life. As Lauren Berlant and Michael Warner have pointed out with respect to heterosexual norms of intimacy, the normal "may never have been an accurate description of how people actually lived" (323). And yet, "this structural relation is no less normative for being imperfect in practice. Its force is to prevent the recognition, memory, elaboration or institutionalization of all the nonstandard intimacies that people have in everyday life" (324). June Howard similarly explains that even though "the home is no haven," even though its walls are exposed as more and more permeable at every turn, even though the boundaries between private and public are "divisions that can never divide," "that does not stop them from having effects. They project bounded entities, set the terms of connectedness, and are woven together in circuits of reciprocally stabilized instabilities with real consequences" (9-10).

Few deny that the dream falls short, that sometimes (if not most of the time) this home sweet home isn't all it's cracked up to be. But the majority hesitates to classify the problem as foundational if they call it a problem at all. That is to say, the ideal still performs regulatory and disciplinary functions: a wide range of existing familial formations are largely defined in relation to it. And if they fail, they are damned as dysfunctional-held individually responsible for instability-because they failed to follow the rules. This inquiry emerges from a nagging suspicion that the less desirable dimensions of suburban privatized domesticity have such staying-power, because they are so intimately and invisibly tied to theories of subjectivity, to self-concepts, to the form and shape people believe themselves to take. At the turn of the twentieth century, architect Michael Sorkin so aptly explains, the home gathered considerable ideological force "as the preserve of the personal, the terrain of our individuation" (193).

With roots extending back to at least the Renaissance, the notion of the house as a domain for the articulation and construction of the private self is obviously not just a twentieth century development. But acute transformations of common-place principles of privacy did occur in the 1910s and 1920s with the emergence of, among other things, new technologies of publicity; a legal definition of personhood as private property; the popularization of psychological discourses about the self; the beginnings of suburbanization; and the growing strength of market mechanisms designed to elicit and sustain specific attachments to home across product packaging, magazine serials, and billboards. Through my research into archives and histories of architecture, urban studies, and popular culture and my encounters with 
literary fictions of home-life, I have become convinced that a particularly cozy relationship between the architectural domestic and a theory of subjectivity as, precisely, privatized enclosure gathered a conspicuous amount of energy at this time. In house planning and interior decorating manuals from the $1920 \mathrm{~s}$, they were analogously modeled and also equated - thereby the house was understood to express the self. ${ }^{1}$ In itself, the conflation provides no necessary cause for social criticism. But when the dwelling-model gravitates toward one singular form that has dominated the production and consumption of such a vast portion of American culture (housing, novels, furnishings, films, etc.), drastically limiting imaginations of alternative material and social forms of dwelling, then the alignments between the domestic and the self could stand some serious renovations.

Consider a passage from a 1916 article about "the pleasant adventures of home making" in one of the popular architecture and interior decorating periodicals, The Craftsman:

Houses are recorders of experience, vouchers of taste or the lack of it. A man's thumb-prints upon paper have no more convincing a variation of individuality than the house he elects to build upon the lot of his choice. The bumps and depressions of a man's head are no more an indication of his character than the windows, porches, roof and doors of his house-were there some new species of phrenologist to interpret them. ("The Story of Home-Making" 216)

If here the house signifies (literally standing in for) the occupant, the individuality of said occupant emerges from an empty lot. The house takes shape from scratch; it has no history, or neighbors for that matter, to speak of. Individuality is selfmade upon a blank slate and only then engaged and interpreted. "A distinct domicile is, indeed, something worth fighting for," as Sorkin argues, in the sense that every single person on earth deserves a home (198). And fair enough is Frank Lloyd Wright's 1908 pronouncement that "[o]ur ideal is Democracy, the highest possible expression of the individual as a unit not inconsistent with a harmonious whole" ("Cause: First Paper" 13). It is his more melodramatic restatement of the idea in his second lecture six years later that should raise some eyebrows: "A great Democracy is the highest form of Aristocracy conceivable, not of birth or place of wealth, but of those qualities that give distinction to the man as a man, and that as a social state it must be characterized by the honesty and responsibility of the absolute individualist as the unit of its structure, then only can we have an Art worthy the name" ("Cause: Second Paper" 42). In a world where the "absolute individualist" is the fundamental unit upon which the social order is built, there is no foundational sense of shared space or collective subjectivities, no room for the very basic idea that my conception of myself as a person comes through my interactions with and compassion for people around me.

If both self and home were conceived as autonomous and detached, they were also ubiquitously prescribed (by social reformers, real estate people, pop-psychologists, and others) as privatized dwellings positioned against the social world, defensive preserves of the personal. Certainly, as another piece in The Craftsman expresses, what sometimes makes a house a home is precisely its relative differ- 
ence from a world "out there"; it should be "a place of constant enjoyment, a refuge from useless annoyance, a place of rest and realization of interests ... a restorer of life and interests, not a drain upon it" ("Small Houses With a Sense of Space" 313). A haven in an occasionally heartless world needs to lock its doors in certain circumstances. But the political and commercial forces behind American households are all too often in the business of restoring certain lives and interests and draining the resources from others. ${ }^{2}$

The following pages interrogate and expand upon Sorkin's conception of the home as a defensive preserve of the personal that structures and is structured by a strong theory of the person as a privatized, free-standing, owner/container of emotions and sexuality. In their imaginations and prescriptions of a good society, architects, urban planners, educators, politicians, women's clubs, and popular periodicals alike equated individuality, independence, and moral virtue with an overwhelmingly suburban conception of private space. They prescribed and legislated inner-directed dwelling practices at the scale of the house, a detached domestic space hermetically sealed from the marketplace, and at the scale of the individual subject, a bound and psychologized interiority. Inside both properly ordered houses and bodies, proper sexuality aligned with romantic intimacy that was heterosexual, coupled, and maintained inside, as a kind of private property. To be a good citizen of a stable nation, it was assumed (and arguably still is) across large sections of built, textual, and visual worlds, one must inhabit an autonomous, detached unit with identifiable boundaries that at once announce its contents to the social world and seal, stabilize, and defend them from it.

The considerable force of these movements inward at the level of housing and subjectivity across architectural and fictional landscapes needs to be confronted, but not fixed or even centralized, in any analysis of early twentieth-century dwelling patterns. I use the language of boundary formation, because I am looking closely at the way that residential lines in social space intersect with conceptual and corporeal grids of subjectivity. "Privates" refer to the discursive and nondiscursive stabilizations of a particularly strong model of domestic interiority that nevertheless makes up only one, albeit very visible, dimension of a far more complicated American landscape. "Proper" homes and bodies were interiorized as social subjects became more mobile across all sorts of borders, as languages diversified and literatures exploded, as social spaces were constituted by visibly conflicting value systems. In the 1920s, floods of immigrants were crossing the nation's borders. Fights for women's rights became increasingly visible. More and more women entered work spaces formerly dominated by men. Divorce rates were on the rise and so was a growing diversity of family types. And sex was commercialized in ways it never had been before. Andrea Friedman explains that only with the emergence of motion pictures, plays, and burlesque shows in the first half of the twentieth century was sexual diversity writ large on the social stage and screen; sexual commodification, in other words, exploded across a range of classes and tastes:

Commercial sex was not limited to the expansion of prostitution. Concert saloons, dance halls, and restaurants all offered public spaces for expressing sexual 
desire and for arranging extramarital liaisons. Images of nude or seminude women could be purchased at cigar stores, were displayed in saloons and pool halls, and could be found in national media like the Police Gazette. Even marital sexuality was drawn into the commercialization of sex, as married women perused advertisements for contraceptives and "female remedies" and availed themselves of the services of professional abortionists. $(18)^{3}$

In response to increasing commercialization, emerging technologies of publicity, and altogether new public spheres which challenged existing boundaries around class, ethnicity, and geography, privacy emerged as a self-conscious principle and the boundaries around certain familial enclosures and bodies became more defensive. If interiority was held up as an ideal, in other words, it was because outsides were felt more intensely.

It is precisely at the edges, then, and not the center of domestic enclaves, where one can begin to analyze textual and material efforts to manage and map threatening social landscapes. It is here also where one might begin to understand that the enclosures produced are tenuous, riddled with fissures and broken seams; borders are crossed all the time; and what Berlant and Warner describe as the queer world- "a space of entrances, exits, unsystematized lines of acquaintances, incommensurate geographies"- may, as it turns out, be the one most of us actually inhabit (322). ${ }^{4}$ And yet, for some reason, beliefs in boundaries separating the home from the rest of the world or some kind of "real" self from the social persist. Exposing them as blurry may constitute only a portion of the intellectual labor necessary for their rearrangement.

In its very form, this essay aims to pull prevailing assumptions about so-called private dwellings and selfhoods away from certain polarities and dead-ends and into a field of greater complexities and opportunities. Sections one and two map the "suburban privates" of households and subjects so that the third section may go about imagining alternative interior architectures, counterprivate frameworks for "feeling at home."

\section{One: Households}

To the Blackburns (a family with mom dad daughter son and dog):

Herewith the plans for a good time space for your family in a style to which you are, as yet, unaccustomed but one which you might truly call your own if you wanted to. We call the style Usonian meaning 'of these United States'... Space is characteristic of this free pattern for a freer life than you could possibly live in the conventional house - separated into boxes; itself a big box... We have studied your little family and arranged for all including the dog. Each has his own privacy when needed and good time space for all together... Betty Jane has a telephone box and all the privacy by the fireplace in the sitting room any young girl has a right to expect before she owns her own home - or her own car. The boys meantime have plenty of room for action... Mother has a convenient kitchen next the dining table - everything 'on ballbearings' to save labor. It is all but autoa right to expect before she owns her own home-or her own car. The boys meantime have plenty of room for action .... Mother has a convenient kitchen next to the dining table- 
everything "on ballbearings" to save labor. It is all but automatic. Father's office is next so mother can answer the telephone when he is away. There is plenty of car space ... A American family life is unlike any other in the world and I think this plan recognizes it for pretty much what it is-at this stage of development-a little private club-with special privacies, ultra conveniences, and style all the while.

\section{-Frank Lloyd Wright ${ }^{5}$}

In his foreword to the 1923 government publication How to Own Your Home: A Handbook for Prospective Homeowners, Herbert Hoover, then Secretary of the U.S. Department of Commerce under the Harding and the Coolidge administrations, wrote:

Maintaining a high percentage of individual homeowners is one of the searching tests that now challenge the people of the United States. The present large proportion of families that own their own homes is both the foundation of a sound economic and social system and a guarantee that our society will continue to develop rationally as changing conditions demand. (v)

After World War I, but before the emergence of mass suburbanization in the likes of Levittown, Hoover motivated a massive political, economic, social, and commercial campaign for individual homeownership. And the ideal American home, a detached, supposedly secure and self-sufficient technological unit, was reproduced in massive quantities to serve as both a foundation for and a shield from a rapidly changing social order. ${ }^{6}$ The 1920 census classified the majority of Americans as either suburban or urban for the first time. Throughout the 1920 s, the population of suburbs increased at twice the rate as the population of cities, and the suburban market tripled between 1920 and 1922 (Wright, Building the Dream 195, 199).

Gwendolyn Wright points out that "most popular middle-class literature, housing guides, and even architects' manuals and government documents praised the suburbs as the haven of "normalcy" (196). At this time, to be normal, wholesome, and happy was to be ensconced in an isolated sphere of domesticity. While, as common history has it, the divisions between private and public zones within the domestic household became more flexible (with the appearance of new spaces like the common living room, for example), the identity of the household as a whole seemed to solidify as a private reserve. A stable home, Hoover insisted as Secretary and eventually as President of the United States, served as the foundation for good citizenship. The proper family of good citizens was accordingly granted a privileged place at the center of a healthy nation, but was both functionally and spatially separated from the rest of society. Increasingly into the 1920 s, the family's function was framed as personal as opposed to political. If the home was taking care of any business, it was doing so behind closed doors, façades of intimacy separating the personal social relationships of everyday life from political, economic, and state concerns.

Although zoning restrictions against noise and pollution predated the twentieth century, zoning laws became the norm only in the 1910 s and ' $20 \mathrm{~s}$, regulating the lay of the land and framing the divisions between residential and commercial or 
industrial areas as "natural."" Anti-urban federal housing programs proliferated, preaching that the livability of residential communities depended on their being precisely distinct from cityscapes considered dangerous to physical and mental health. The aforementioned government publication, How to Own Your Home, directed its readers to insulate their homes from everything but domestic life:

If a city is zoned it is almost always safest to buy in a residential district where there is safety from intrusion by factories, public garages, and scattered stores... If there is no zoning law, how about private restrictions?... If even one or two lots near by are unrestricted, objectionable buildings might be erected on them... Are the private restrictions such that a home will surely be protected? (Gries and Taylor 11)

Homeownership guides were published to educate the public as to proper ways of living but also to sell these residential arrangements. With the Hoover administration, there emerged an extremely widespread and successful housing business. An open letter from John M. Gries, the Chief of the Division of Building and Housing at the Department of Commerce and one of the authors of How to Own Your Home, placed inside the front cover of the guide reads: "It is our belief that if home ownership is to increase and become a basis for a progressive citizenship, the home seeker should have sound financing machinery available, that his investment should be as free as possible from unnecessary hazards and that he should be given in general a reasonable opportunity to attain his purpose." In 1908, Sears Roebuck, acting as mortgage bank, architect, contractor, and builder all in one, started selling small, relatively low-cost houses ("Mass-produced Houses" 54). By the 1920s, in conjunction with the emergence of the automobile (which Hoover calls the "great impulse to suburban life" [v]), the government and the housing industry massively coordinated their efforts to move people out into planned suburbs, and the mid1920 s witnessed an enormous boom in the production of single-family homes. ${ }^{8}$ The house became an object to be bought, sold, and reproduced in the marketplace.

Not only was the domestic marketed, but it also became a target market itself. According to urban and architectural historian Dolores Hayden, for example, "[a]dvertising and marketing firms spent 1 billion dollars to promote private domestic life and mass consumption in 1920; their annual volume had risen over 1,000 percent since 1890 and continued to rise throughout the 1920s" (274). Ironically, the media for this marketing campaign (such as the radio) continually permeated the boundaries of the house. In other words, it is precisely as the envelope of the house became more explicitly vulnerable to the forces of the market that those same market forces, in cooperation with politicians, social reformers, urban planners, and architects, circulated the ideology of a free-standing, impermeable domestic interiority.

Early twentieth-century prescriptive literature, home-making and -decorating manuals and periodicals, and architectural manifestos continued to frame domestic architecture as a strong determinant of behavior and values, but they shifted away from the nineteenth-century emphasis upon moral patterns of living toward a much more individualist agenda promoting honest personality and character over fleet- 
ing and transitory forms. As that which formally marked the border between inside and outside, the domestic enclosure's façade became more and more critical to the proper functioning of home-life and was judged according to its honesty-whether it genuinely and accurately communicated or translated its inner purpose. The outward appearance of the home, in other words, was required to designate, express, authenticate that which it contained-the private life of an American family of free citizens. For Frank Lloyd Wright, for example, the house functioned not merely to signify, but somehow to authenticate the individuality of its occupantto "idealize the character of the individual it is fashioned to serve more intimately" ("Cause: First Paper" 21, 24). Accordingly, he argued, "[t]here should be as many kinds (styles) of house as there are kinds (styles) of people and individuals" (1011). ${ }^{9}$ Because it operated as an external indicator of interiority, the honest domestic façade had to look different from public architecture in order to express hominess. ${ }^{10}$ To put it another way, the façade indicated the separateness of home from the outside on the outside. By the second decade, there was a growing opposition to the use of industrial-looking elements to build homes:

Claim[ing] that the traditional building materials were those best adapted to the rooted, solid institution of the house, and that the chief materials of mass production-metals, fabrics, and plastics - would be ill-adapted to housing, ... the foes of fabrication deposed that a man's home is wreathed in sentiment as is no other inanimate object. ("Mass-produced Houses" 52)

Although Sears Roebuck led the way in pre-fabrication, their manufactured domestic spaces, designed to appear "homey" and precisely not part of the business world, "neatly stylized in the suburban manner with accents of Colonial New England," clearly reflect these general sentiments ("Mass-produced Houses" 54). Today, developers continue to make a whole lot of money mass-producing the "faces" of suburban privates, feeding a growing desire for the images of quaint communities and picket fences. ${ }^{.1}$

\section{Two: Subjects}

In his own home thus the Broadacre citizen would be not only impregnable. He would be inviolate. This nation indestructible! . . . He is his country.

-Frank Lloyd Wright

The socio-economic and affective orders that materialized through the built environment in the early twentieth century applied in remarkably similar ways to the self. "A free America, democratic in the sense that our forefathers intended it to be, means just this individual freedom for all ... freedom in space.... The home of the individual social unit will contain in itself in this respect all the city heretofore could afford, plus intimate comfort and free individual choice" (Wright, "Modern Architecture" 74, 76). Frank Lloyd Wright's prolific declarations about privacy and individual liberty could be found everywhere in his many lectures and books, as well as in the pages of popular women's periodicals like Ladies Home Journal. "It 
is the essence of Democracy that the individual man is free in his body and free in his soul .... It is the ideal of Democracy that the individual man should stand selfcentered, self-governing - an individual sovereign, an individual god," his early employer and mentor, Louis Sullivan, wrote (141). Wright and Sullivan render a free-standing, self-governing sphere of individuality that is the privatized liberal subject par excellence. It is the theoretically autonomous figure who inhabits a landscape of impossibly distinct boundaries between the public and the political, on the one hand, and an interiorized private on the other. It is the subject for whom much American legal and political theory and practice is based and according to whom so many dimensions of American social and personal space are imagined and materialized, and it gained considerably strong currency in the 1910s and 1920s. The outer shape and the substance of this subject, so it goes, remains universally the same on the face of American politics. Each to an acre. ${ }^{12}$ And the personal, the peculiar, the idiosyncratic mingle happily together inside property lines.

So much more than a privilege, privacy became an individual right prerequisite to a healthy national body. This wasn't always the case. Privacy used to have a privative trait, according to Hannah Arendt:

It meant literally a state of being deprived of something, and even of the highest
and most human of man's capacities. A man who lived only a private life, who like
the slave was not permitted to enter the public realm, or like the barbarian had
chosen not to establish such a realm, was not fully human. We no longer think
primarily of deprivation when we use the word "privacy," and this is partly due
to the enormous enrichment of the private sphere through modern individualism
(38).

At the turn of the twentieth century, the private enclosures of modern individualism so enriched at the expense of the public also demanded legal protection from the public. It was only in 1890, with Louis Brandeis and Samuel Warren's Harvard Law Review article entitled "The Right to Privacy," that a principle of privacy was legally established to regulate and discipline traffic around, into, and through private spheres. In his extremely informative historical review of the right to privacy, William L. Prosser explains that Brandeis and Warren's article did not have an immediate effect upon the American legal, economic, and cultural landscapes: "For the next thirty years there was a continued dispute as to whether the right of privacy existed at all" (384-386). ${ }^{13}$ Prosser's point is worth reiterating, because it illustrates that the dimensions of the private sphere of individualism were highly ambiguous and that the private's relationship to the legal constitution of individual subjects was up for heated academic and popular debate across various legal, social, and cultural institutions from the late 1890 s through the $1930 \mathrm{~s} .{ }^{14}$ During this time, in other words, privacy was becoming constitutive of personhood.

The idea of privacy emerged primarily in response to technologies of publicity - to protect individuals from invasions by "the too enterprising press, the photographer, or the possessor of any other modern device for recording or reproducing scenes or sounds" (Brandeis and Warren 206). ${ }^{15}$ It was a defensive principle designed to provide refuge from the modern world and its "unseemly gossip": 
The intensity and complexity of life, attendant upon advancing civilization, have rendered necessary some retreat from the world, and man, under the refining influence of culture, has become more sensitive to publicity, so that solitude and privacy have become more essential to the individual; but modern enterprise and invention have, through invasions upon his privacy, subjected him to mental pain and distress, far greater than could be inflicted by mere bodily injury. (196)

The principle defended not just domestic possessions and corporeal private space, but "the thoughts, sentiments, and emotions, expressed through the medium of writing or of the arts" as well as "the personal appearance, sayings, acts and ... personal relation[s] domestic or otherwise" of an individual person-thereby rendering the social exogenous to a very wide range of practices legally cordoned off as "the personal" $(205,213)$. All such personal attributes and behaviors, Brandeis and Warren argued, are "instance[s] of the enforcement of the more general right of the individual to be let alone" (205):

\begin{abstract}
It is like the right not to be assaulted or beaten, the right not to be imprisoned, the right not to be maliciously prosecuted, the right not to be defamed. In each of these rights, as indeed in all other rights recognized by the law, there inheres the quality of being owned or possessed - and (as that is the distinguishing attribute of property) there may be some propriety in speaking of those rights as property. But, obviously, they bear little resemblance to what is ordinarily comprehended under that term. The principle which protects personal writings and all other personal productions, not against theft and physical appropriation, but against publication in any form, is in reality not the principle of private property, but that of an inviolate personality. (205)
\end{abstract}

Brandeis and Warren understood the right to privacy to be "a part of the more general right to the immunity of the person - the right to one's personality" (207). This "extended and unusual sense" of property legally defined the individual person as a private space, a bounded personality requiring its own legislation, policing, and protection.

If the emergence of the legal principle of privacy was a reaction to intruding technologies of the public, the values that came to be associated with the private sphere also emerged in response to what Robert Wiebe describes as the functionalism of the public sphere in the early twentieth century. Providing a very clear analysis of the professionalization and the systematization of public spaces and institutions, he argues that, "[a]rriving around 1900 and gaining momentum after 1910 , the bureaucratic orientation did not reach its peak of success until the nineteen twenties" (149). I want to expand and revise Wiebe's claims that bureaucratic society "obliterated the inner man" (148). Indeed, within bureaucratic frameworks, "the focus had shifted from essences to actions," and "the new ideas concerned what men were doing and how they did it" (148). But the rationalization of political, social, and educational institutions in public led precisely to an intensification of something called the "inner life" in private. ${ }^{16}$ As bureaucratic efficiency increasingly characterized social institutions, the intimate sphere functionally and spatially separated and protected the "human" side of life; it was where the person was 
cultivated and made whole. To sum up, if Wiebe is right, and the rhetoric of functionalism reached its peak in the 1920s, the function of the private spaces of domesticity and personhood, in turn, was to house those qualities that were not oriented toward bureaucratic efficiency-to protect the inner self.

During these first two decades, the inner self became thoroughly pop-psychologized. And, predictably, it gathered enormous attention as a target of the advertising industry, a trend that distinguishes twentieth-century advertising from earlier practices, according to design historians Ellen Lupton and J. Abbott Miller: "By 1900 the notion of advertising as a benevolent advertising information service gave way to more aggressive and sophisticated strategies. Pamphlets, lectures, and articles on 'advertising psychology' appeared as early as 1896" (184). Textbooks such as Walter Dill Scott's The Theory of Advertising and The Psychology of Advertising emphasized advertising's power of suggestion and defined the consumer in a new way: as a manipulable subject motivated not by reason, but by impulsive desires. A new field called "market research" appeared, and along with it, what I am calling the psychologization of separate spheres, the mystification of social normative gender categories as psychological. "J. Walter Thompson, then one of the largest firms in the country, added, in 1919, a statistical and investigation department and two planning departments - one for male and one for female consumers" (187). Armed with experts' knowledge from this departmental structure of separate spheres, advertisers played upon the insecurities and desires of their target markets; for example, "fear was frequently turned to the advantage of business through advertisements that played upon the insecurities of women as inadequate dates, wives, mothers, or housekeepers" (187).

It is not difficult to make the transition from the convergence of the pseudoscientific psychologization of the inner self with the mechanisms of the market to this period's overwhelming preoccupations with identity, especially sexual identity. Indeed, it is impossible to fully understand early twentieth-century working concepts of identity without also taking into consideration prevailing attitudes towards sexual difference, or deviance, as it were. On the one hand, the self was conceived as a depth that escaped social systematization. But on the other, the self became a bound interiority that could, in the interests of the social (sexual) order, be contained - a privatized enclosure to be named and identified, its boundaries regulated accordingly. The definition of sexuality radically shifted at this timefrom outer-directed behaviors and desires to identity, a personal trait to be uncovered through a close hermeneutic reading of the subject. With the relocation of sexuality to the insides of body, it became the private property of atomized subjects, hidden, but retrievable if necessary, and subject to discipline if not properly maintained. ${ }^{17}$ Anti-obscenity campaigns and vice crusaders reigned, rigorously legislating boundaries around proper expressions of sexuality. Already ripe with the research of sexologists attracting a wide range of the population, this period marked the advent of pathologized and "deviant" sexualities on an institutional scale. The same sexual advice literature advocating self-government and individual management of one's own borders and surfaces called for the establishment of external regulations for those who couldn't control themselves. ${ }^{18}$ 


\section{Three: Counterprivates}

The actual alternative to the received and produced fixed forms is not silence: not the absence, the unconscious, which bourgeois culture has mythicized. It is a kind of feeling and thinking which is indeed social and material, but in an embryonic phase before it can become fully articulated and defined exchange. Its relations with the already articulated and defined are then exceptionally complex.

-Raymond Williams

My concerns about models of defensive enclosure are driven, in large part, by contemporary legislations of social bodies and spaces that privatize housing and subjectivity in the face of intimate relations between people who don't adhere to the heterosexual couple formation or the detached nuclear family. The policing of public sexual culture at the center of the 42nd Street Development Project in New York City over the last few years reminds me that the deconstruction of dominant social structures is emphatically not an outdated critical activity. ${ }^{19}$ As I study the impact of domestic form on subjectivity, I think about particular ways that sexual difference and orientation, as well as skin color and economic class, get figured into or out of contemporary models of dwelling. If there is a sense of urgency fueling my analyses of the forces of privatization which have been cleansing public spaces, policing bodies, and fueling narrow-minded educational policies for almost ten decades, however, I am at the same time acutely aware of the need to analyze and reposition these forces as one set of multiple factors contributing to the multiple and intersecting layers of social relations and landscapes that coexisted in the early twentieth century. An emerging opposition between a social sphere and an intimate one at the turn of the twentieth century speaks to a state of acute vulnerability. But not everyone felt the need to secure a personal space away from the social world. While divisions between the home and the marketplace, between private realms and public spheres, did and still do order a significant portion of the American landscape, there existed other modes of dwelling and practices of subjectivity that did not take such predictable forms.

If Jeffrey Masten asks, "How will we read, interpret, conceptualize, organize, and edit texts written before the birth of the author in its modern (self-possessed and sexually orientated) incarnation" (9), I am asking: How might we read, interpret, conceptualize, organize, and edit spaces designed and texts composed in the early twentieth century that don't fit this self-possessive framework? Rather than engage the still valuable work of deconstruction or reiterate the various problems with the dominant ideologies of privacy, the remaining pages of this essay seek to develop a language through which other modes of inhabitation that existed alongside defensive enclosures may be better understood. I resist framing these alternative spatialities as exceptions or even reactions to the rule. Instead, I am trying to find the tools with which we might positively explore other(ed) spaces-to discover what they do rather than what they don't do.

I take very seriously Eve Sedgwick's warnings about paranoid reading. Sedgwick explains that the "paranoid critical stance" has become "nearly synonymous with criticism itself" (4): "Subversive and demystifying parody, suspicious 
archaeologies of the present, the detection of hidden patterns of violence and their exposure ... these teachable protocols of unveiling have become the common currency of cultural and historicist studies" (21). Operating according to a false consciousness model, the paranoid critic assumes that her job is to decipher, to expose dominant power relations that structure any given site (for Sedgwick, the site in question is the literary text; I am here concerned more broadly with material and textual practices of domestic interiority). The problem with this widespread critical habit is that while such a practice can expertly reveal how certain social systems operate to constrain, it simply cannot see how those same systems might enable and, moreover, it is largely blind to other relations that may be shaping the site. Furthermore, the demystification of power structures may not contribute so much after all to their actual dissolution. Placing all "faith in exposure," Sedgwick argues, the paranoid critic acts "as though to make something visible as a problem were, if not a mere hop, skip, and jump away from getting it solved, at least selfevidently a step in that direction" (17). Nowadays though, most everyone knows in their popular cynicism that ideologies are contradictory; even the media likes to laugh at the artificiality of gender representations. So "what is the basis for assuming that it will surprise or disturb-never mind motivate-anyone to learn that a given social manifestation is artificial, self-contradictory, imitative, phantasmatic, or even violent?" (19). Drawing upon the work of Melanie Klein and Silvan Tomkins, Sedgwick wants to make space for what she calls reparative reading practices - "methodologically adventurous" ways of reading (3) that are "more interesting, more responsive, more truthful, and more useful as we try to account for [our work's] motives in a less stylized fashion than we have been" (23). Reparative readers acknowledge the realities of oppression without fixing them. They explore "the extremely varied, dynamic, and historically contingent ways that strong theoretical constructs interact with weak ones in the ecology of knowing" (23), and they look closely for relations and desires in texts that have "not (yet?) resolved into a sexual specificity of proscribed object choice, aim, site, or identification" (2). "To read from a reparative position is to surrender the knowing, anxious paranoid determination that no horror, however apparently unthinkable, shall ever come to the reader as new: to a reparatively positioned reader it can seem realistic and necessary to experience surprise. Because there can be terrible surprises, however, there can also be good ones" (24). The possibility of other worlds drives the reparative reader, not the inevitability of the present ones. Reparative reading is not meant to replace paranoid criticism as I understand it. It is a mode of thinking, reading, and writing that deserves to take up adjacent and complementary spaces in our scholarship and teaching.

I offer the term counterprivate to critically complement two recent trends in architecture and social theory, which are themselves reparatively driven by the possibility of other words, alternatives to past and present mappings of domesticity, privacy, and the public. First, the unprivate house, the central figure of the 1999 Museum of Modern Art exhibition curated by Terence Riley, challenges conventional private dwellings by highlighting the permeability of their boundaries and/or undoing them. The exhibition praises the "unsentimental pose[s]" of 
unprivate houses spanning the twentieth century for the way they expose, in their formal arrangement and design, objects and practices that are usually kept private (26). In the accompanying narrative, Riley suggests that in the age of digital media and public exhibitionism, "the splendid isolation envisioned by [Frank Lloyd] Wright" may be outdated, that these unprivate houses offer a progressive alternative to the intimacy - publicity dichotomy (17). As the framing figure suggests, however, the exhibition does not seek an alternative state of being at home, whatever that may mean. The house is either private in the conventional sense or it is slyly, playfully, or cynically deconstructed and turned inside out.

Second, the counterpublic sphere so central to recent queer public sphere criticism practiced by Berlant and Warner, among others. This is the place where affects, behaviors, and attachments dwell in neither "the official publics of opinion culture and the state" nor "the privatized forms normally associated with sexuality" (322). It is the site for non-normative intimacies that aren't allowed in public space "proper" (which, as Berlant points out, is actually constituted by "simultaneously lived private worlds" [Queen 5]) and that certainly won't settle for the predictable formations of the "inside." Because private residences for normative sexual relations and citizenship have increasingly replaced more diverse public cultures, Berlant and Warner argue, it is central to queer culture to make public other "kinds of intimacy that bear no necessary relation to domestic space, to kinship, to the couple form, to property, or to the nation" (322). A counterpublic in this sense is always unstable, "an indefinitely accessible world conscious of its subordinate relation" to the existing arrangement of private and the public spheres (322), but rich with transformative, "collective world making" energies (Warner, Publics 57). Gestures, encounters, and collaborations that have no canon, more ephemeral productions in social space and in print culture, connections between people who are for various reasons not visible as a community or an identity, mobile sites that are not supported by dominant architectures of domesticity-these have the potential to produce other spatialities.

Counterpublic criticism has much in common with Raymond Williams's work around what he calls "structures of feeling." The movement through and beyond the subject positions made visible by institutional discourses is the movement between what Williams describes as "the ruling definition of the social," on the one hand, and that which, through the processes of exclusion, "may often be seen as the personal or the private" (125). He interrogates the common-sense world as composed of various modes of spatiality that are not all organized in terms of dominant discursive categories. Structures of feeling, in so far as they exist beneath the level of the concept, pose the possibility of oppositional practices to the dominant culture. The dominant is never all-encompassing: "No dominant social order and therefore no dominant culture ever in reality includes or exhausts all human practice, human energy and human intention" (125). That which is designated as the personal and private, the self and the body, can be sites of resistance. The stutterings and the slippages, the bodily gestures gone awry, the missed communications, the unexpected points of contact ... they often fall between the cracks of dominant social norms. But unless the dominant discourse's gaps and fissures 
are publicized, that is to say, unless the dimensions of the self and the body are conceptualized as public products of social relations rather than bounded interior personalized spaces, such normative representations will not be challenged to the extent that they should be. It is important to depersonalize structures of feeling, to get them out into the open, to break them out of their contained spaces.

Whether they concern the complex processes involved in the consolidation of boundaries around the private or the opposites, failures, leaks, and loose ends of such consolidations, much contemporary literary and social criticism frames the private as a site to be demystified, exposed, questioned, deconstructed - a repressed, stifling, "obnoxiously cramped" space from which progressive social criticism must run, a bourgeois trap, an effect of bad ideology (Warner, Publics 194). In Warner's Publics and Counterpublics, for example, the term is almost always used in conjunction with regressive conceptions of identity based upon the fiction of some kind of pre-social stable ground for the self (see 208). He critiques the current conditions of the private self, privacy as a product of "heteronormative conventions of intimacy," which

conjure a mirage: a home base of pre-political humanity from which citizens are thought to come into political discourse and to which they are expected to return in the (always imaginary) future after political conflict. Intimate life ... is the endlessly cited elsewhere of political public discourse, a promised haven that distracts citizens from the unequal conditions of their political and economic lives, consoles them for the damaged humanity of mass society, and shames them for any divergence between their lives and the intimate sphere that is alleged to be simple personhood. (193)

If this is clearly a limited (when not utterly disabling) formation of the private, I am wondering if there is a private to be differently imagined with respect to complex personhood? How might the private be conceived within alternative contexts for living? Are there privates that are attendant to the more flexible indexes for social membership collectively constructed by counterpublics?

As we seek to articulate affects and relations that exist outside the bounds of normative privacies, I wonder whether it might be useful to wander back into less predictable formations of the inside, architectures of intimacy that do not merely support or reinforce standard forms of intimacy, models of individualism that are committed to making space for an inner life but not defensively detached from outerworlds. Counterprivates run contrary to the "right" course. They offset (as in counterattack), reject (as in counterculture), or thwart the efforts of (as in counterintelligence) dominant ideologies of privacy. They exist simultaneously with socalled established privates but move in an opposite direction-not opposite from the public, but opposite from the kind of private stuck in that dichotomous relationship with the public. The always shifting morphologies of the counterprivate are profoundly un-sum-up-able, but they will likely share at least three major aspects: 1) relative autonomy from what is understood to be the "public," 2) a non-defensive posture towards this "public," and 3) non-identitarian attachments or relations to the self. 
First, while never forgetting that the dimensions of the private space of the house and of the person have everything to do with the social coordinates which plot work, leisure, romance, gender, and sexuality, I am concerned to disarticulate counterprivates from social institutions - to insist on a connected but non-necessary relationship between certain formations of the private and normative structures. In response to some feminist theorists' fears "that attention to the surface and the outside denies the affectivity of interiority," Elspeth Probyn argues that we should be careful not to oppose interiority to social construction (12). ${ }^{20}$ It makes more sense, she explains, to investigate "the forces which constitute the outside and the inside as dichotomous" (12). But if interiority is always socially constituted, are all interiorities stuck within this socially constituted dichotomous relationship? That is to say, are there insides that are not the opposites or the other sides of outsides?

Take, for example, T. J. Jackson Lears's now classic analysis of the coalescence of architectural and subjective interiority for the late nineteenth- and early twentieth-century middle classes. Lears argues that the turn of the century domestic interior, "increasingly called upon to harbor all the emotional warmth and intimacy that had been banished from the calculating world outside" (5), turned into a hyperpersonalized escapist haven, "an arena for exotic performance and theatrical illusion" (7), "an essential refuge for cultivating personal identity" that was only apparently set off from the modern technological and commercial world (14). Both the self and home became "theatre[s] for performance," their stage sets furnished "with high-style consumer goods" (14): "The sanctioned way to foster these illusions was by purchasing and assembling mass-marketed commodities so that the interior might harbor a more fluid self, adrift amid the objects of its fantasies" (7). Lears sets up a strong dichotomy between the commodity-obsessed consumers duped by the market into endlessly remaking themselves, "unstable selves who try to solidify their existence through high-style consumption," and the core interior authentic selves longed for by many a modernist writer (15). But is there a third space between or alongside a commodified self and an imagined core interior self? Are all subjects trying to solidify their existences? Is there a performative interiority to endlessly developing selves that is not slave to the market, that can be granted some degree of critical autonomy?

Second, the private need not be a defensive space of refuge or resistance. The point here is not to discount the importance of "the home as a place of security" and "the confidence in the house as providing shelter and security" (Rainwater 9394). ${ }^{21}$ Sociologist Lee Rainwater finds that the more threatening the social environment, the more acute the longing for a boundary that designates a necessarily defensive domestic interiority. His analysis serves as a much-needed reminder that blurry, heterogeneous spaces cannot be treated as categorically positive, but it also reveals the dominance of a middle-class ideal of privacy that suppresses other kinds of valuable interactions. The only available solution to unsafe living arrangements, in other words, seems to be the middle-class suburban dwelling legislated by a neighborhood association that deals with social problems. Moving up the socio-economic ladder, so to speak, means that safe common spaces that are cre- 
ated in higher-risk neighborhoods - semi-private outdoor spaces and common indoor spaces, like the hallway shared by multiple families - disappear in favor of detached dwelling. And interactions between "families" become less and less spontaneous. ${ }^{22}$

Barry Schwartz similarly points out the important functions of privacy in the struggle for individuality, especially in oppressive situations in which the ego needs to put up defenses: "Privacy prevents the ego from identifying itself too closely with or losing itself in (public) roles" (136). Likewise, Erving Goffman provides a provocative analysis of "the practice of reserving something of oneself from the clutch of an institution" (319). He argues that "this recalcitrance is not an incidental mechanism of defense but rather an essential constituent of the self" (319). In any social organization, an individual "employ[s] methods to keep some distance, some elbow room between himself and that which others assume he should be identified" (319). Goffman's articulation of the self as a "stance-taking entity, a something that takes up a position somewhere between identification with an organization and opposition to it, and is ready at the slightest pressure to regain its balance by shifting its involvement in either direction" is, largely, a defense model of individualism: "It is thus against something that the self can emerge" (320). But his own question - "If we find then, that in all situations actually studied the participant has erected defenses against his social bondedness, why should we base our conceptions of the self upon how the individual would act were conditions 'just right'?"- suggests that a reconceptualization of the self might begin to understand such distancing, reservation, and recalcitrance as something other than defensive; in other words, it may be possible to reframe this residue of selfhood that doesn't slot smoothly into given social categories of organization (that "often resides in the cracks" of "the solid buildings of the world") in its positivity and moreover, as Goffman articulates so well, as a practice (320).

It follows, then, that defensiveness should be understood as a temporary, situational, and symptomatic state, not a foundational quality of privacy. Under better circumstances, the private can be created and inhabited as a non-defensive interiority, a "free space," to use the phenomenological language of Maurice Merleau-Ponty, which allows embodied subjects to carry out their own projects in the world, to act in and on their surroundings (see 98-147). Merleau-Ponty's "free space" is no doubt utopian in the sense that social norms operate otherwise. Political theorist and philosopher Iris Marion Young, for example, brilliantly articulates the effects of oppressive gender norms as precisely the felt corporeal and psychological constriction of such "free space." For many women, she explains, "a space surrounds us in imagination that we are not free to move beyond; the space available to our movement is a constricted space" (146). She also adds that "the space that is physically available to the feminine body is frequently of greater radius than the space that she uses and inhabits" (151). In other words, when a subject is oppressed as a body by social norms of femininity her space as a free subject sometimes seems to start inside her skin - the surface of the body felt to be a social ground - and the body is experienced as an enclosure. Far from a social privilege, this interiority is experienced as an effect of social norms that frame or inscribe a 
subject along its corporeal boundaries. It is this kind of interiority, as I understand it, that becomes the object of various anti-racist, feminist, and queer critiques of essentialist philosophies and politics that are structured around a logic of identity that makes claims about what people are. In this sense, the subject-as-enclosure more accurately serves as an indicator of an oppressed social subject rather than a descriptor of empowered selfhood.

Third, the private need not bind to the self as a protective or stabilizing apparatus of personality or identity. Young's recommendation that "political theory would do well to disengage social group difference from a logic of identity" affects not only conceptualizations of the political, public culture, and social justice; it profoundly concerns theories of the private (82). For in order to "conceptualize social groups according to a relational rather than a substantialist logic" and affirm that "groups do not have identities as such, but rather that individuals construct their own identities on the basis of social group positioning," the private forms of citizenship upon which contemporary American political rhetoric and policy are based clearly need to be dismantled and reconceived (82). Counterprivates support a form of individualism based upon a freedom that is not substantive, that is less a characteristic or descriptor of being than a condition for action. They bear a non-identitarian relation to the self, enabling - but neither containing nor expressing-dimensions of subjectivity and domesticity conventionally understood to be private and personal. As frames for private transformation, they have boundaries that articulate permeable and connected spheres of flexible use and creative inhabitation, zones that are not defined by any fixed content (emotions, secrets, nuclear family, skeletons, monogamous sex) or set of properties (pitched roof, four walls, family feel, ethnic background, heterosexual orientation, distance from neighbor), but by how they function. ${ }^{23}$ To borrow from legal scholar Patricia Williams's reconceptualization of legal rights, they are flexible states of inwardness wherein "privacy is turned from exclusion based on self-regard into regard for another's fragile, mysterious autonomy" (92). Counterprivates move away from a model of interiority whereby idiosyncrasies, differences, and failures reside inside each atomistic and disconnected "house of rights," embracing instead the profound irreducibility of the adjacent other. And they respect the ungraspable perplexities of the self, what Marcel Proust beautifully renders in the following passage as the non-ego inhabiting the most intimate of places:

I leave it to people of taste to make of their rooms the very image of their taste, and to fill them only with things of which they can approve. As for me, I feel myself living and thinking in a room where everything is the creation and the language of lives profoundly different from mine, of a taste opposite to mine, where I find nothing of my conscious thought, where my imagination is excited by feeling itself plunged into the depths of the non-ego ... where in the evening, when opening the door of one's room, one has the feeling of violating all of the life that has remained scattered there, of taking it boldly by the hand when, once the door is closed, one enters farther, up to the table or the window; to sit with it in a kind of free promiscuousness on the sofa designed by the upholsterer of the local county in what he believed to be the style of Paris; to touch everywhere the nakedness of 
that life with the intention of being troubled by one's own familiarity, by putting here and there one's things, by pretending to be the master of that room full to the brim with the soul of others and which keeps even in the shape of its andirons and the pattern of its curtains the imprint of their dreams, by walking barefoot on its unknown carpet; one has then the feeling of shutting in with oneself this secret life, when one goes, all trembling, to bolt the door; of pushing it in front of one onto the bed and finally lying down with it under the large white sheets which come up over one's face .... $(17,19)$

One's own strangers in residence are not ghostly invasions of the homely that need to be expelled. They constitute a precious and generative unfamiliarity that is a welcome not a threat to a self utterly vulnerable to its outsides.

In conclusion, there are two broad goals motivating my wide-eyed and openended appeals for counterprivates: to rethink the suburban model of interiority upon which many a household of the self is based and to rearrange the domestic itself so that the house might not figure as a stabilizing ground for subjectivity. If a site so intimately linked to narratives of identity and belonging is to be a practicing place productively linked to the social world, it can be secure without being a static foundation for the fiction of pre-social selves. As so many developments in architecture and urban planning, legal and political frameworks of liberalism, and literary and educational discourses around the text still tightly entangle the privatized domestic and the subject, whereby one is assumed to contain and express the other, it seems like a pressingly good time to not merely unhouse the subject, but set up some new digs.

\section{Notes}

'For example, Frank Alvah Parsons writes: "The house is but the externalized man; himself expressed in colour, form, line, and texture .... It is he" (vii). A browse through any issue of The Craftsman from this period also demonstrates multiple variations of this pattern. For the explicitly gendered aspects of such conflations, whereby the female body is aligned with the domestic interior, see Post 200; de Wolfe 5, 18, 21; Burbank xi; Gordon.

${ }^{2}$ For a very dense investigation of different historically-situated relations between family structures and civic life and an argument against neoconservatives and liberal humanists' assumptions of a natural relation between the two, see Shapiro.

${ }^{3}$ For excellent histories of commercialized sex from the mid-nineteenth to the twentieth century, see D'Emilio and Freedman; Erenberg; Kasson; Gilfoyle; Mumford; Peiss.

${ }^{4}$ George Chauncey charts a "gay life ... more integrated into the everyday life of the city in the prewar decades than it would be after World War II" (3). Chauncey convincingly argues that the urban landscapes of sexual culture before 1940 were not subject to a strictly binary framework of sexual identity. The most visible gay worlds, he claims, were grounded in working-class cultures where the labels "homo" and "hetero" were not dominant until the middle of the twentieth century.

${ }^{5}$ For an excellent analysis of Wright's middle-class conventions and clientele, see Twombly.

${ }^{6}$ Oddly enough, Hoover resided at the Waldorf-Astoria in New York City. For a more detailed explanation of Hoover's influence, see Wright, Building the Dream 193-214. Gwendolyn Wright also discusses the 1922 Better Homes in America Movement, the more 
explicitly commercial arm of this effort. For an overview of late nineteenth-century defensive domesticities, see Sennett; Warner, Streetcar Suburbs.

${ }^{7}$ The first zoning ordinance was passed in Los Angeles in 1909, and New York established land use regulations in 1916, but it was not until the 1920s, when smaller cities and suburbs adopting zoning regulations, that they had the biggest impact (Wright, Building the Dream 213). See also McKenzie 299-301; U.S. Department of Commerce.

${ }^{8}$ Motor vehicle registration doubled between 1920 and 1930, from 9 million to 20 million (Wright, Building the Dream 207; Historical Statistics 223). As president, Hoover held a conference in 1931 advocating single-family home ownership, which led to the development of 50 million homes housing three quarters of American families (see Gries and Ford; Hayden 9-10). The overproduction of single-family dwellings, in fact, produced a crisis during the years leading up to the Depression, when thousands of these houses were left unoccupied because they were too expensive ("Mass-produced Houses"). Since the Depression, Gwendolyn Wright points out, "housing in the United States has been circumscribed by federal guidelines .... The government has set standards for construction, for financing, for land-use planning, and, to a certain extent, for family and community life" (218). Wright also points out that after World War II, the federal government actively promoted widespread building of suburban developments, slum clearance, urban renewal programs, and the building of highways - all of which deeply segregated American communities, most of them explicitly so (220-239).

${ }^{9}$ The is part of Wright's nationalist project. Complaining of Americans' tendencies to copy other civilizations rather than produce their own "originals," of the American "habit to fashion appearances rapidly into a nation-wide cult in lieu of genuine culture," of the commodification of "America's own nature," he puts forth this call for regionalism:

Why not then, take hold ourselves of this interior native content awaiting deliverance in our Culture in our own minority report and ourselves gradually build with it a Nation where no commodity can hope for success except as it contributes not only to the ease and wealth of the Nation, but contributes as well to the integrity of the Nation considered as created for the spirit of Man-not merely for men. ("Prospectus" 2-3)

${ }^{10}$ From the very beginning of the practice of architecture in the United States, domestic and public architecture were treated differently-not just programmatically, of course, but stylistically. At the end of the eighteenth century, Thomas Jefferson built his private houses in the Palladian style and reserved Classicism for public buildings. It is important to point out that the difference between inner-city architecture and suburban architecture wasn't just one of taste or security - it had everything to do with the institution of architectural education at this time. In the second half of the nineteenth century, it was understood that the best American architectural students (Louis Sullivan, Richard Morris Hunt, Henry Hobson Richardson, and Charles McKim, to name just a few) went to Paris to study at the École des Beaux-Arts,

which exercised a strong influence on recently established schools of architecture in America, and where for several decades Americans were in a majority among overseas students . . . As this relationship grew in the second half of the nineteenth century, so inner-city architecture in America came increasingly under the influence of the École des Beaux-Arts, whilst in the suburbs and in the countryside autonomous developments continued. (Kruft 345-355)

${ }^{11}$ For a variety of disciplinary approaches to the study of the front lawn as an extension of the domestic façade, see Jenkins; Teyssot; Diller. 
${ }^{12}$ Each individual family unit received an acre in Frank Lloyd Wright's various utopian schemes. All plans were decentralized to avoid the social and moral problems he considered endemic to overcrowded cities. Broadacre City, for example, was designed as a series of largely self-subsistent homesteads for the average five-person nuclear family. Early plans included only detached houses for residences. A later tract accommodated apartment buildings and hotel facilities, but only on the outskirts of the City, beyond a waterway which served as a barrier between the residential and industrial zones. See Wright, The Disappearing City, When Democracy Builds, The Living City. For a critique of Broadacre City's pseudo-cooperative organization, see Zellman and Friedland.

${ }^{13}$ Prosser's article is both a historical review of the right to privacy and an analysis of its separate components (freedom from intrusion, public disclosure of private facts, misrepresentation in public, wrongful appropriation of identity) as we have come to understand the principle today (389). For a thorough list of early twentieth-century law review discussions of the right to privacy, see Prosser $384 \mathrm{n}$.

${ }^{14}$ Over the course of at least two or three centuries, intense dialogue and debate over the creation and definition of private property can be found with respect to copyright laws and practices. Here, I am concerned with the private property that becomes synonymous with personhood in the early twentieth century.

${ }^{15}$ The larger story here concerns the commodification of privacy, made possible by new technologies such as the camera. It is not a unidirectional movement from the public into the private. The private, in many cases, makes itself available for public consumption. Roland Barthes says it best in the following passage: "The age of photography corresponds precisely to the explosion of the private into the public ... or rather into the creation of a new social value, which is the publicity of the private: the private is consumed as such, publicly" (98).

${ }^{16}$ This is, of course, not an original claim. Georg Simmel famously described the split metropolitan type at the turn of the twentieth century in his 1903 essay "The Metropolis and Mental Life."

${ }^{17}$ For an excellent overview of the pathologization of non-normative sexual practices in the late nineteenth and early twentieth centuries, see D'Emilio and Freedman 171-235.

${ }^{18}$ Andrea Friedman begins her study of Comstock's reign with the 1909 establishment of the National Board of Censorship of Motion Pictures, "a New York based organization that offered the first institutional articulation of the principles underlying democratic moral authority" (21). According to Friedman, sexual materials and expressions were judged not only by their purportedly "indecent" content, but by their potential to elicit "indecent" responses (i.e., lust, arousal, deviant thoughts and behaviors) from their readers or viewers (17). She explains that this "dual emphasis ... made possible the successful prosecution of serious works of social criticism, sex education tracts, advertisements for contraceptives, and outright pornography alike" (17). The Comstock laws deemed most expressions of sexuality "outside" the private domestic sphere indecent, immoral, and obscene; sexuality was not allowed to take up social space.

${ }^{19}$ For provocatively different takes on the redevelopment of 42 nd Street, see Delaney. For a multi-pronged response to contemporary conservative sex education agendas and for links to organizations that act out against the systematic policing and purification of public space, see also Managing Desire. In one of the best pieces I've encountered on the complex moral and financial forces behind zoning laws, Alison Redick argues that the Redevelopment Project under Mayor Rudy Guiliani's reign can be traced back to vice campaigns in the 1920 s and ' 30 s that targeted brothels and saloons. For similar work, see Dangerous Bedfellows.

${ }^{20}$ Biddy Martin, for example, argues that "too exclusive an understanding of psychic life as the effect of normalization can impoverish the language we have available for thinking 
about selves and relationships, even as they apparently enrich our vocabularies for thinking about social construction" (106).

${ }^{21}$ Rainwater's analysis points to the class-specificity of the concept of the house as an expression of the self. Lower classes, he explains, may exist in tension with their homes, and he argues that only after "the battle to make the home a safe place has long been won" does the home have "more central to its definition other functions which have to do with selfexpression and self-realization" (93).

${ }^{22}$ On the importance of semi-public spaces to working- and lower-class families, see Yancey.

${ }^{23}$ Because the primary aim of this essay is to develop the historical and theoretical framework for counter-formulations of private dwelling, I have chosen to leave out analyses of specific past and contemporary architectures that I believe productively engage in counterprivate practices of the self and home. Such work, of course, falls into the broader scope of this project. Here, I will mention just two of several possible architects who may be preoccupied with shaping private spheres of flexible use and creative inhabitation. First, Rudolph M. Schindler conceived of his houses, especially his own 1921-1922 Kings Road House, as profoundly permeable "frames for living." The text accompanying a recent major exhibition, The Architecture of R M. Schindler, serves as an excellent introduction to Schindler's philosophy and work. Second and more recently, Lebbeus Woods's philosophies and materializations of "free-zones"- experimental architectures of indeterminacy for "a type of free interaction-a dialogue with oneself" (15)-strongly parallel my descriptions of the counterprivate.

\section{Works Cited}

Arendt, Hannah. The Human Condition. 1958. 2nd ed. Chicago: University of Chicago Press, 1998.

Barthes, Roland. Camera Lucida: Reflections on Photography. Trans. Richard Howard. New York: Hill \& Wang, 1981.

Berlant, Lauren. The Queen of America Goes to Washington City: Essays on Sex and Citizenship. Durham, NC: Duke University Press, 1997.

Berlant, Lauren, and Michael Warner. "Sex in Public." Intimacy. Ed. Lauren Berlant. Chicago: University of Chicago Press, 2000. 311-330.

Brandeis, Louis D., and Samuel D. Warren. "The Right to Privacy." Harvard Law Review 4.5 (1890): 196-220.

Burbank, Emily. Woman as Decoration. New York: Dodd \& Mead, 1917.

Chauncey, George. Gay New York: Gender, Urban Culture and the Making of the Gay Male World, 1890-1940. New York: Basic Books, 1994.

Dangerous Bedfellows, eds. Policing Public Sex: Queer Politics and the Future of AIDS Activism. Boston, MA: South End Press, 1996.

Delaney, Samuel. Times Square Red, Times Square Blue. New York: New York University Press, 1999.

D'Emilio, John, and Estelle Freedman. Intimate Matters: A History of Sexuality in America. Chicago: University of Chicago Press, 1988.

De Wolfe, Elsie. The House in Good Taste. New York: Century Co., 1913.

Diller, Elizabeth "The American Lawn: Surface of Everyday Life." The Art of Architecture Exhibitions. Ed. Kristin Feireiss. Rotterdam: Netherlands Architecture Institute, 2001. 42-49.

Erenberg, Lewis A. Steppin' Out: New York Night Life and the Transformation of American Culture, 1890-1930. Westport, CT: Greenwood Press, 1981. 
Friedman, Andrea. Prurient Interests: Gender, Democracy, and Obscenity in New York City, 1909-1945. New York: Columbia University Press, 2000.

Gilfoyle, Thomas. City of Eros: New York City, Prostitution, and the Commercialization of Sex, 1790-1920. New York: Norton, 1992.

Goffman, Erving. Asylums: Essays on the Social Situation of Mental Patients and Other Inmates. Garden City, NY: Doubleday, 1961.

Gordon, Beverly. "Woman's Domestic Body: The Conceptual Conflation of Women and Interiors in the Industrial Age." Winterthur Portfolio 31.4 (Winter 1996): 281-301.

Gries, John M., and James Ford. President's Conference on Home Building and Home Ownership. Washington, D.C.: President's Conference on Home Building and Home Ownership, 1932.

Gries, John M., and James S. Taylor. How To Own Your Home: A Handbook for Prospective Homeowners. Washington, D.C.: U.S. Government Printing Office, 1923.

Hayden, Dolores. The Grand Domestic Revolution: A History of Feminist Designs for American Homes, Neighborhoods and Cities. Cambridge, MA: MIT Press, 1981.

Helmer, John, and Neil A. Eddington, eds. Urbanman: The Psychology of Urban Survival. New York: Free Press, 1973.

The Historical Statistics of the United States. Washington, D.C.: U.S. Government Printing Office, 1952.

Hoover, Herbert. Foreword. Gries and Taylor i-viii.

Howard, June. Publishing the Family. Durham, NC: Duke University Press, 2001.

Jenkins, Virginia Scott. The Lawn: A History of an American Obsession. Washington, D.C.: Smithsonian Institution Press, 1994.

Kasson, John. Amusing the Million: Coney Island at the Turn of the Century. New York: Hill \& Wang, 1978.

Kruft, Hanno-Walter. A History of Architectural Theory from Vitruvius to the Present. Trans. Ronald Taylor, Elsie Callander, and Antony Wood. New York: Princeton Architectural Press, 1994.

Lears, T. J. Jackson. "Infinite Riches in a Little Room: The Interior Scenes of Modernist Culture." Modulus 18 (1987): 3-27.

Lupton, Ellen, and J. Abbott Miller. "Graphic Design in America." Design Writing Research: Writing on Graphic Design. New York: Princeton Architectural Press, 1996. 168-202.

Managing Desire. Ed. Nicolas Sheon. HIV Prevention Section of the Berkeley Free Clinic, Interdisciplinary Working Group on HIV/AIDS Representations and Practices. Doreen B. Townsend Center for the Humanities, University of California-Berkeley. 4 Sept. $2003<$ http://www.managingdesire.org>.

Martin, Biddy. "Sexualities Without Genders and Other Queer Utopias." Diacritics 24.2-3 (1994): 104-121.

"Mass-produced Houses in Review." Fortune April 1933: 52-57+.

Masten, Jeffrey. Textual Intercourse: Collaboration, Authorship, and Sexualities in Renaissance Drama. Cambridge, UK: Cambridge University Press, 1997.

McKenzie, R. D. The Metropolitan Community. New York: McGraw-Hill, 1933.

Merleau-Ponty, Maurice. Phenomenology of Perception. Trans. Colin Smith. London: Routledge, 1962.

Mumford, Kevin J. Interzones: Black/White Sex Districts in Chicago and New York in the Early Twentieth Century. New York: Columbia University Press, 1997.

Parsons, Frank Alvah. Interior Decoration: Its Principles and Practice. Garden City, NY: Doubleday, 1922.

Peiss, Kathy. Cheap Amusements: Leisure in Turn-of-the-Century New York. Philadelphia, PA: Temple University Press, 1985. 
Post, Emily. The Personality of a House: The Blue Book of Home Design and Decoration.

New York: Funk \& Wagnalls, 1930.

Probyn, Elspeth. Outside Belongings. New York: Routledge, 1996.

Prosser, William L. "Privacy." California Law Review 48.3 (August 1960): 383-423.

Proust, Marcel. On Reading. 1905. Trans. and Ed. Jean Autret and William Burford. New York: Macmillan, 1971.

Rainwater, Lee. "Fear and the House-as-Haven in the Lower Class." Helmer and Eddington 92-106.

Redick, Alison. "The Mixed Constituency of Sexual Commerce." Sex Panic NYC. 20 June $2000<$ www.geocities.com/ sexpanicnyc $>$.

Riley, Terence. The Un-Private House. New York: Harry N. Abrams, 1999.

Schindler, Rudolph M. The Architecture of R M. Schindler. Ed. Elizabeth Smith and Michael Darling. Los Angeles: Los Angeles Museum of Contemporary Art, 2000.

Schwartz, Barry. "The Social Psychology of Privacy." Helmer and Eddington 123-141.

Scott, Walter Dill. The Psychology of Advertising. New York: Dodd \& Mead, 1908.

-. The Theory of Advertising. Boston: Small, Maynard, 1903.

Sedgwick, Eve Kosofsky. "Paranoid Reading and Reparative Reading; or, You're So Paranoid, You Probably Think This Introduction Is About You." Novel Gazing: Queer Readings in Fiction. Ed. Sedgwick. Durham, NC: Duke University Press, 1997. 1-37.

Sennett, Richard. Families Against the City: Middle Class Homes of Industrial Chicago, 1872-1890. Cambridge, MA: Harvard University Press, 1984.

Shapiro, Michael J. For Moral Ambiguity: National Culture and the Politics of the Family. Minneapolis: University of Minnesota Press, 2001.

Simmel, Georg. "The Metropolis and Mental Life." 1903. Georg Simmel on Individuality and Social Forms. Ed. Donald N. Levine. Chicago: University of Chicago Press, 1971. 324-339.

"Small Houses with a Sense of Space." The Craftsman 30.3 (June 1916): 313-318.

Sorkin, Michael. Exquisite Corpse: Writing on Buildings. New York: Verso, 1991.

"The Story of Home-Making." The Craftsman 30.2 (May 1916): 216-219.

Sullivan, Louis H. "The Young Man in Architecture." Louis Sullivan: The Public Papers.

Ed. R. Trombly. Chicago: University of Chicago Press, 1988. 131-144.

Teyssot, Georges. The American Lawn. New York: Princeton Architectural Press, 1999.

Twombly, Robert. "Saving the Family: Middle Class Attraction to Wright's Prairie House, 1901-1909." American Quarterly 27.1 (March 1975): 57-72.

U.S. Department of Commerce. A Standard City Planning Enabling Act by the Advisory Committee on City Planning and Zoning Appointed by Secretary Hoover. Washington, D.C.: U.S. Government Printing Office, 1928.

Warner, Michael. Publics and Counterpublics. New York: Zone Books, 2002.

Warner, Sam Bass. Streetcar Suburbs: The Process of Growth in Boston, 1870-1900. New York: Athenaeum, 1971.

Wiebe, Robert H. The Search for Order: 1877-1920. New York: Hill and Wang, 1967.

Williams, Patricia J. "Alchemical Notes: Reconstructing Ideals from Deconstructed Rights." Critical Race Theory: The Cutting Edge. Ed. Richard Delgado. Philadelphia, PA: Temple University Press, 1995. 84-94.

Williams, Raymond. Marxism and Literature. New York: Oxford University Press, 1977.

Woods, Lebbeus. Anarchitecture: Architecture is a Political Act. New York: St. Martin's, 1992.

Wright, Frank Lloyd. The Disappearing City. New York: W. F. Payson, 1932.

-. "In the Cause of Architecture: First Paper." 1908. Frank Lloyd Wright: The Complete 1925 “Wendingen” Series. New York: Dover Publications, 1992. 8-24. 
- "In the Cause of Architecture: Second Paper." 1914. Frank Lloyd Wright: The Complete 1925 “Wendingen" Series. New York: Dover Publications, 1992. 25-47.

—. The Living City. New York: Horizon Press, 1958.

- "Modern Architecture, being the Kahn Lectures." 1931. Frank Lloyd Wright: Collected Writings. Vol. 2. Ed. Bruce Brooks Pfeiffer. New York: Rizzoli International Publications, 1992. 19-79.

—. "Prospectus: Hillside Home School of the Allied Arts, October 1931." Frank Lloyd Wright Collection, Getty Research Institute.

-. When Democracy Builds. Chicago: University of Chicago Press, 1945.

Wright, Gwendolyn. Building the Dream: A Social History of Housing in America. Cambridge, MA: MIT Press, 1981.

Yancey, William L. "Architecture, Interaction, and Social Control: The Case of a Large-Scale Public Housing Project." Helmer and Eddington 107-122.

Young, Iris Marion. Inclusion and Democracy. New York: Oxford University Press, 2000.

Zellman, Harold, and Roger Friedland. "Broadacre in Brentwood? The Politics of Architectural Aesthetics." Looking for Los Angeles: Architecture, Film, Photography, and the Urban Landscape. Ed. Salas and Roth. Los Angeles: Getty Research Institute, 2001. 167-210. 